\title{
Kişilik Özelliklerinin İşsizlik Kaygısı Üzerine Etkisi: Üniversite Mezunları Üzerine Bir Araştırma
}

\author{
DOI: 10.26466/opus. 926760
}

\author{
Hasan Dağlar* \\ * Dr. Öğr. Üyesi, Çankırı Karatekin Üniversitesi, İ.̇̇.B.F., Çankırı/Türkiye \\ E-Posta: hdaglar@karatekin.edu.tr \\ ORCID: $\quad \underline{0000-0002-6903-8141}$
}

\section{Öz}

Bu araştırmanın amacl; işsiz olup iş arayan üniversite mezunlarının işsizlik kaygı düzeylerinin çeşitli sosyo-demografik değişkenler açısından istatistiki olarak anlamlı farklılıkları olup olmadığııın tespit edilmesi, ayrıca farkh kişilik özelliklerinin işsizlik kaygısı üzerine etkilerinin incelenmesidir. Bu araştırma, Çankırı Karatekin Üniversitesinden mezun olmuş 36.604 kişi ile yapılmış olup, iş aradığını ve işsiz olduğunu belirten 1261 kişi araştırmaya katılmıştır. İ̧ arayan üniversite mezunlarının 36 sorudan oluşan anket formunu cevaplandırmalarıla araştırma verileri toplanmış, kurulan hipotezler test edilmiş ve sonuçları analiz edilmiştir. Üniversite mezunlarının iş aradıkları süreye göre, 1-3 yıl arası iş arayanların işsizlik kaygılarının diğer gruplardan daha yüksek olduğu görülmüştür. Kişiliközelliklerinden deneyime açıklık ve dışa dönüklük bağımsız değişkenlerinin, işsizlik kaygısı bağımlı değişkeni üzerinde istatistiki olarak anlamlı bir etkisinin olmadığı bulunmuştur. Dışa dönük ve deneyime açık kişilik özellikleri gösterenlerin diğgerlerine göre daha az işsizlik kaygısı duyduğu görülmüş̧ür. Uyumluluk, sorumluluk ve duygusal denge bağımsız değişkenlerinin ise, işsizlik kaygısı üzerinde istatistiki açıdan anlamlı bir etkisinin olduğu tespit edilmiştir. Uyumluluk, sorumluluk ve duygusal denge kişilik özelliklerine sahip olanların işsizlik kaygılarının daha fazla olduğu görülmüştür.

Anahtar Kelimeler: Kişilik, İssizlik, Kayg̨, Üniversite Mezunu. 


\title{
The Effect of Personality Traits on Unemployment Anxiety: A Research on University Graduates
}

\begin{abstract}
The purpose of this study is to determine whether there are statistically significant differences in unemployment anxiety levels of unemployed university graduates who are looking for a job in terms of various socio-demographic variables and to examine the effects of different personality traits on unemployment anxiety. This research was conducted with 36.604 graduates of Çankırı Karatekin University, and 1261 people who stated that they were unemployed and looking for a job participated in the study. The research data were collected after job seeking university graduates answered the 36 survey questions, and the established hypotheses were tested and the results were analyzed. According to the duration of job seeking university graduates, it has been observed that the unemployment anxiety of the job seekers between 1-3 years is higher than the other groups. It was found that the independent variables of extraversion and openness to experience, which are among the personality traits, did not have a statistically significant effect on the unemployment anxiety dependent variable. It is observed that individuals with openness to experience and extroversion personality traits have less unemployment anxiety than others. It was determined that independent variables of compatibleness, responsibility and emotional balance has a statistically significant effect on unemployment anxiety. It was found that those who have personality traits of compatibleness, responsibility and emotional balance have more unemployment anxiety.
\end{abstract}

Key Words: $\quad$ Personality, Unemployment, Anxiety, University Graduates. 


\section{Giriş}

Çalışmak istediği halde iş bulamama yani işsizlik günümüzde önemli bir sorun haline gelmiştir. İş bulamama gençlerde ve özellikle üniversite mezunu işsizlerde daha çok psikolojik, ekonomik ve sosyal sorunlara yol açabilmektedir.

İşsizlik, azgelişmiş ve gelişmekte olan ülkelerde büyük bir sorun olarak görülmektedir. Türkiye'de yükseköğretim mezunlarının işsizlik sorunu genel işsizlik sürecini takip etmekte hatta çoğu zaman genel işsizlik oranlarını aşmaktadır. Bu durum iş gücüne dahil olmak isteyen üniversite mezunlarında iş bulma ve işsizlik kaygısına neden olabilmektedir.

Üniversite eğitiminin amaçlarından birisi kişilere gereken eğitimi vererek, çeşitli sektörlerde çalışabilecek şekilde iş hayatına hazırlamaktır. Türkiye'de üniversite mezunlarının genellikle ilk hedefi kamu ya da özel sektörde iş bulup istihdam edilebilmektir. Türkiye'de üniversite mezunu sayısının hızla artmasına rağmen, bunların istihdam edileceği iş imkanlarının aynı oranda artmaması yükseköğretim mezunlarının işsizlik kaygısı yaşamalarına neden olmaktadır.

Türk Dil Kurumu (TDK) sözlüğünde kaygı; üzüntü, endişe duyulan düşünce, tasa ve genellikle kötü bir şey olacakmış düşüncesiyle ortaya çıkan ve sebebi bilinmeyen gerginlik duygusu olarak açılanmaktadır. Kaygı, güçlü bir istek ya da dürtünün amacına ulaşamayacak gibi gözüktüğü durumlarda beliren tedirgin edici bir duygudur (TDK, 2021).

İşsizlik kaygısı, kişilerin iyi bir eğitim alıp iyi bir iş bulmayı ümit ettikleri üniversitelerin bölümlerine giriş aşamasından itibaren başlayabilmektedir. Kişilerin işsizlik kaygıları, üniversite öğrenciliği zamanında ve üniversiteden mezun olup iş bulamadıklarında da devam edebilmektedir.

Türkiye'de genel işsizlik oranları Türkiye İstatistik Kurumu verilerine göre, Ekim 2020 tarihi itibariyle \%12.7 ve yükseköğretim mezunlarının işsizlik oranlarının \%14 civarında yüksek seyretmesi, önemli bir sosyal ve ekonomik sorun olarak görülmekte ve bu durum üniversite mezunlarının işsizlik kaygısı yaşamalarına neden olmaktadır. Özellikle uzun bir eğitim sürecini tamamlayarak üniversiteden mezun olan ve iş bulma ümidiyle hayata atılan yükseköğretim mezunu gençlerin, işsizlik sorunu ile 
karşılaşmaları ve işsizlik kaygısı duymaları araştırılması gereken önemli bir sorun olarak görülmektedir.

$\mathrm{Bu}$ araştırmanın amacl; işsiz olup iş arayan üniversite mezunlarının işsizlik kaygı düzeylerinin çeşitli sosyo-demografik değişkenler açısından anlamlı farklılık gösterip göstermediğinin tespit edilmesidir. Ayrıca farklı kişilik özelliklerinin işsizlik kaygısı üzerine etkilerinin incelenmesidir.

\section{Üniversite Mezunlarının İşsizliği ve İş Bulma Kaygısı}

Birey açısından işsizlik, çalışma isteğinde, yeteneğinde ve çalışmaya hazır bir durumda olmasına rağmen, kişinin gelir elde edebileceği bir işe sahip olamama durumudur. İşsizliğin toplum açısından tanımı ise, en değerli üretici kaynak olan iş gücünün bir kısmının kullanılamaması boşa harcanmasidır (Talas, 1997, s.128).

Türkiye İstatistik Kurumu (TÜIKK)'e göre işsiz; referans dönemi içinde istihdam halinde olmayan kişilerden iş aramak için son dört hafta içinde iş arama kanallarından en az birini kullanmış ve iki hafta içinde işbaşı yapabilecek durumda olan kişidir. TÜİK, kurumsal olmayan çalışma çağındaki tüm kişileri işsiz olarak ele almakta ve bu kişileri işsiz nüfusa dahil etmektedir (TÜİK, 2021, s.9).

Tablo 1. Türkiye'de 15-64 yaş grubu genel işsizlik ve yükseköğretim mezunlarının işsizlik oranlarn (\%)

\begin{tabular}{llll}
\hline \multicolumn{1}{c}{ İşsizlik Grupları } & & $\mathbf{2 0 1 9}$ & $\mathbf{2 0 2 0}$ \\
\hline 15-64 Yaş Grubu Genel İşsizlik Oranları & Toplam & 13.4 & 12.7 \\
& Erkek & 11,7 & 11.5 \\
& Kadın & 17.0 & 15,5 \\
Yükseköğretim Mezunlarının İşsizlik Oranları & Toplam & 13.8 & 14.0 \\
& Erkek & 10.0 & 11.2 \\
& Kadın & 19.2 & 18.0 \\
\hline
\end{tabular}

Kaynak: TÜİK, İsgücü İstatistikleri, 11.01.2021.

Tablo 1'de görüldüğü gibi Türkiye genelinde $15-64$ yaş grubundakilerde işsizlik oranı 2020 yılı Ekim döneminde \%12.7 seviyesinde gerçekleşmiştir. Yükseköğretim mezunlarının işsizlik oranı ise \%14 ile genel işsizlik oranının üzerinde seyretmektedir. Türkiye'de Yükseköğretim mezunlarının işsizlik oranı 2019 yılında \%13.8 iken, 2020 yılında \%14'e yükselmiştir. 2020 yılında yükseköğretim mezunu erkek 
işsizlerin oranı \%11.2 iken, kadın işsizlerin oranı \%18 olmuştur. Yükseköğretim mezunu kadınların erkeklere oranla daha fazla işsiz oldukları görülmektedir.

İşsizlik, kişilerin kendine güven ve kendine saygının kaybı, endişe ve depresyon gibi psikolojik rahatsızlıklara yol açabilmektedir. İşsizliğin, yükseköğretim mezunu eğitimli işsizlerin ruh sağlığı üzerinde daha fazla olumsuz etkisinin olduğu görülmüştür. Yükseköğretim mezunlarının uzun süre eğitimini aldıkları mesleği yapamamanın sıkıntısı ve geleceğe dönük beklentilerinin gerçekleşmemesi bu kişileri bunalıma sürükleyebilmektedir. Ancak eğitimli kişiler işsizliği, çaresizlikten çok geçici bir durum olarak kabul etmektedirler (Kurt, 2006, s.372).

Kaygı, kişinin günlük hayatının merkezi olur ve kişi kaygı üzerinde odaklanırsa o zaman kişi duyduğu kaygıdan dolayı davranış bozuklukları gösterebilir. Kaygıdan kaynaklanan davranış bozuklukları; sürekli gerginlik, terleme, kalp çarpıntısı, üzülme, dikkati toplamada zorluk, çabucak sinirlenme, tedirgin bekleyiş hali ve panik halleridir. Kaygı, çeşitli seviyelerde hemen hemen herkeste bulunabilirken, şiddeti ve sürekliliği arttığı zaman bir problem olarak ortaya çıkabilmektedir (Cüceloğlu, 2017, s.441).

İşsizlik kaygısı, kişinin çalışma isteğinde olup piyasadaki ücretlere razı olduğu halde, iş bulamaması sonucunda ortaya çıkan üzüntü, endişe ve gerginlik durumu olarak açıklanabilir. Üniversite mezunu işsiz kişi, iş arayıp iş bularak işsizlik kaygısından kurtulmaya çalışır.

Üniversite öğrencilerinin iş bulmayla ilgili kaygı seviyeleri her geçen gün artmakta ve küresel rekabetle birlikte işsiz üniversite mezunu kavramı yaygınlaşmaktadır. Üniversite öğrencileri için işsizlik ve gelecek endişesi en büyük kaygı kaynağı olarak görülmektedir. Üniversite mezunlarında ve gençler arasında işsizliğin fazla olması, üniversite mezunu sayılarının hızla artması işsizlik kaygı düzeyini daha da artırmaktadır (Eş ve Durak, 2018, s.117).

Türkiye'de 2021 yılı itibariyle 129 devlet, 74 vakıf olmak üzere toplam 203 üniversite bulunmaktadır. Önlisans, lisans ve lisansüstü seviyelerinde üniversitelerde eğitim öğretim gören toplam öğrenci sayısı 7.940.133'e ulaşmıştır. 2019 yılında üniversitelerden toplam 891.458 öğrenci mezun olmuştur (Yükseköğretim Bilgi Yönetim Sistemi, 2021). 
Günümüzde yükseköğretim kurumlarından mezun olan öğrenciler işsizlik oranlarının yüksek olmasından veya daha iyi iş bulabilmek amacıyla yüksek lisans yapma, iş sınavlarına hazırlanma, yabancı dil öğrenme gibi çeşitli kurslara ve eğitim programlarına katılarak niteliklerini artırmaya çalışmaktadırlar. Kişiler üniversiteden mezun olduktan sonra da bilgi, beceri ve donanımlarını artırarak iş bulma rekabetinde ön plana çıkmaya gayret etmektedirler. Üniversite mezunlarının iş aramada ve iş bulmada kullandığı kanallar; işverene veya işletmeye bireysel başvurular, medyadaki ilanlar, İ̧̧KUR' un iş ve meslek danışmanlığ 1 hizmeti, özel istihdam büroları, akraba ve tanıdık, gazete, ilan, dergi, sosyal medya ve internet kanalları olmaktadır.

İşsizlik süresindeki artışla birlikte işsizliğin yıkıcı etkilerinin arttığı, işsizlik süresindeki artışın kişilerin hissettiği bıkkınlığı artırdığı ve iş arama yoğunluğunu azalttığ1, işsiz kişilerin uzun süre işsiz kalmalarının iş arama çabalarını azaltabildiği belirlenmiştir (Şentürk, 2019, s.627).

İş bulamama ve işsizlik durumu kişilerde stres oluşturabilmekte, ekonomik, sosyal ve psikolojik olumsuzluklar meydana getirebilmektedir. İşsizlik, yükseköğretim mezunu gençlerde kaygı, düşük özsaygı, depresyon, suçluluk, hayal kırıklığı, gelecekten umutsuzluk, öfke ve çaresizlik duygularına ve sosyal ilişkilerde bozulmalara yol açabilmektedir (Kicir, 2017, s.1390).

\section{Kişilik}

Kişilik; insanın, konuşma, düşünme, hissetme, olaylara ve insanlara bakış şekilleriyle, doğuştan getirdiği ve sonradan kazandığı, onu diğer insanlardan ayıran özelliklerin tamamını ifade eder. Kişilik, bireyi kendisi yapan, onu diğerlerinden ayıran, kendine özgü kılan kalıcı özelliklerin bütünüdür. Kişi tutarlı olarak zaman boyutu içinde aynı durumlarda aynı davranışı göstermekte yani davranışı fazla değişmemektedir (Güney, 2017, s.299).

\section{Kişiliğin Belirlenmesinde Kullanılan Beş Faktör Kişilik Ölçeği}

Beş faktör kişilik ölçeği, çok sayıdaki kişilik özelliklerini daha aza indirerek ölçebilmek amacıyla geliştirilen ve kişiliği ölçmede yaygın olarak 
kullanılan ölçeklerden biridir. Beş faktör kişilik ölçeği, kişiliğin beş temel boyuttan oluştuğunu ileri sürmekte ve kişilik özelliklerini dişa dönüklük, sorumluluk, uyumluluk, duygusal denge ve deneyime açılık olarak beş alt boyutta toplayıp ölçmektedir. Beş faktör kişilik ölçeği, kişiliğin ölçümünde çok sayıda araştırmayla desteklenmiş, geçerlilik ve güvenilirliği yüksek bir ölçektir. Ölçek, insanların kişilik yapılarını belirlemek için kullanılan sıfatların, faktör analizi sonucu geliştirilmiş ve kişiliği beş alt faktörle sinırlandırmıştır (Tutar, 2016, s.63).

\section{Beş Faktör Kişilik Özelliklerinin Alt Boyutları}

Dışa dönüklük: Girişimci, etkin, hevesli, girişken, dışa dönük, sosyal, olumlu duygulara sahip ve heyecan arayan kişilerin dişa dönüklük özelliği yüksek olup, bu alt boyutta yüksek puan alan kişilerdir. Bu özelliklerin aksine içine kapanık, sessiz ve yalnız kalmayı seven kişiler dışa dönüklük özelliği düşük olan kişilerdir (Rammstedt ve Oliver, 2007, s.208).

Sorumluluk: Öz disiplini yüksek, güvenilir, yetkin, başarma duygusu yüksek, müzakere edebilen azimli, hırslı, titiz, düzenli ve disiplinli kişiler sorumluluk alt boyutunda yüksek puan almaktadırlar. Dağınık, dikkatsiz, tembel özellikleri olan kişilerin sorumluluk kişilik özelliği düşük olmaktadır (Costa vd. 1991, s.888).

Uyumluluk: Çabuk uyum sağlayan, tevazu sahibi, yumuşak başlı, alçakgönüllü, hassasiyet gösteren, güven duyulan, şefkatli, fedakârlık gösteren, sempatik, sıcak kişilik özelikleri gösterenler uyumlu kişiler olarak adlandırılmaktadır. Eleştirici, bencil, kavgacı ve geçimsiz özellikler gösteren kişiler ise uyumluluk alt boyutunda düşük puan almaktadır (Costa vd. 1991, s.888).

Duygusal denge: Endişeli, kolayca üzülen, kaygıll, kızgın, çabuk sinirlenen, gergin, depresyonda olan ve insanlara karşı düşmanlık hisleri olan özellikler kişiliğin duygusal denge alt boyutunda toplanmakta ve bu özellikleri gösteren kişilerin duygusal dengesi düşük çıkmaktadır. Bu özelliklerin aksine sakin, rahat, duygusal olarak kararlı özellikler gösteren ve 
kendine güvenen kişilerin duygusal denge düzeyi yüksek olmaktadır (Rammstedt ve Oliver, 2007, s.208).

Deneyime açıklık: Yeniliklere, yenilikçi fikirlere ve deneyimlere açık, değişikliği seven, estetik özellikleri yüksek, hayal kuran, yeni fikirlere ve değerlere çok ilgi gösteren, meraklı, maceracı kişilik özellikleri, deneyime açıklık alt boyutunda toplanmaktadır. Geleneksel, değişime direnen, yaratıcı olmayan, mevcudu muhafaza etme gayretinde olan, yeniliklere kapalı kişilerin deneyime açıklığı düşük olmaktadır (Gosling vd. 2003, s.525).

Kişilik özelliklerinin belirlenmesinde yararlanılan ölçeklerin çok uzun olması, kişiler tarafından doldurulmalarının çok zaman alması ve veri toplamanın zorluğundan dolayı, daha kısa ölçeklerin geliştirilmesi yoluna gidilmiştir. Beş faktör kişilik özelliklerini dolaylı olarak çok sayıda soru sormak yerine, doğrudan daha az sayıda soru sorarak belirlemeye yönelik ölçekler geliştirilmiştir.

\section{Alan Yazın Tarama}

Yapılan alan yazın taramasında işsizlik kaygısı üzerine yapılan araştırmaların, üniversitede eğitim öğretime devam eden öğrencilerle yapıldı̆̆ görülmektedir. Ancak üniversite mezunu olup henüz iş bulamamış işsizlerin, kişilik özelliklerinin işsizlik kaygısı ile ilişkilerini doğrudan inceleyen araştırmalara rastlanamamıştır. İşsizlik kaygısı ile ilgili yapılan araştırmaların çoğunun veri toplama zorluğundan dolayı üniversite mezunlarıla değil, üniversitede okuyan ve mezun olunca iş bulup bulamayacağı henüz belli olmayan öğrenciler üzerinde yapıldığı görülmektedir. $\mathrm{Bu}$ araştırmanın, üniversiteden mezun olmuş, işsizlik sorunuyla karşılaşmış iş arayan üniversite mezunu işsizler üzerinde yapılmış olması dolayısıyla alana katkı sağlayacağı düşünülmektedir.

Üniversite öğrencileri arasında işsizlik kaygısı üzerine yapılan bir araştırmada, üniversite son sınıf öğrencilerinin en önemli kaygılarının iş bulamama endişesi olduğu, işsizliğin fazla olmasının bu kaygıyı daha çok artırdığı belirtilmiştir. Mezun olduktan sonra iş bulma konusunda ümidi olmayan ögrrencilerin sürekli ve durumluk kaygı düzeylerinin, iş bulma 
konusunda ümidi olanlara göre daha yüksek olduğu tespit edilmiştir (Dursun ve Aytaç, 2009, s.81).

İssizliğin meydana getirdiği psikolojik rahatsızlıklar üzerine yapılan bir araştırmada, işsiz kişilerde aşırı kaygı, endişe, korku, kendini yetersiz görme, depresyon, özgüvenin yitirilmesi ve gerginlik görüldügü belirtilmiştir. İşsizlerin kendilerine olan güvenlerini kaybedebildikleri, öz yeterlik düzeylerinde ve hayat tatminlerinde azalma, depresif duygularda artış, stres düzeylerinde yükselme görüldüğü tespit edilmiştir (Güler Kümbül, 2006, s.377).

Üniversitede okuyan öğrencilerin işsizlik kaygıları ve psikolojik dayanıklılık seviyeleri arasındaki ilişkileri inceleyen bir araştırmada, üniversiteli kadın öğrencilerin işsizlik kaygı düzeylerinin erkek öğrencilerden anlamlı düzeyde daha yüksek olduğu belirlenmiştir. Bunun temel nedeninin, iş piyasasında üniversite mezunu erkeklerin kadınlara göre daha kolay iş bulabilmeleri olduğu ifade edilmiştir (Taşğın vd. 2017, s.563).

Kişilik özellikleriyle işsizlik arasındaki ilişkileri inceleyen bir araştırmada, dışa dönük ve uyumlu kişilerin işsizlik sürelerinin daha az olduğu, iş bulup işsizlikten kurtulmayla beraber nevrotik kişilik özelliklerinde bir azalma olduğu tespit edilmiştir (Viinikainen, ve Kokko, 2012, s.1220).

İssizlik kaygısının öğrencilerin girişimcilik niyetiyle ilişkisi üzerine yapılan bir araştırmada, üniversite son sınıf öğrencilerinin işsizlik kaygısı yaşadıkları, bunun sebebinin ekonomideki istihdam zorluklarından kaynaklandığ1 ve üniversite mezunu sayılarının sürekli artmasının iş bulma ümidini azalttığ ifade edilmiştir. İşsizlik kaygısı ve girişimcilik niyeti arasındaki ilişkinin istatistiki açıdan anlamlı, pozitif yönde ve zayıf bir ilişki olduğu tespit edilmiştir (Karcıoğlu ve Balkaya, 2018, s.118).

Meslek Yüksekokulu mezunları üzerine yapılan bir araştırmada; cinsiyet ve mezun olunan bölümle ilgili çalışma durumu değişkenleri açısından, mezunların kaygı durumlarında istatistiksel olarak anlamlı bir farklılık bulunamamıştır. Mezunların çalıştıkları işle ilgili memnuniyetlerinin kaygı puanları arasında istatistiksel olarak anlamlı bir farklılık bulunmuştur. Kaygının nedeni olarak mezun iş bulanların iş buldukları için memnun olmalarına rağmen, iş piyasasının değişken bir yapıya sahip olmasından dolayı işini kaybetme kaygısı duymalarından kaynaklandığı ileri sürülmüştür (Tektaş, 2014, s.252). 
İşsizliğin psikolojik sonuçları üzerine yapılan bir araştırmada, erkek işsizlerin kadınlara göre işsizlik sürecinden psikolojik olarak daha olumsuz etkilendikleri ayrıca işsizlik durumunun evli bireyleri daha kötü etkilediği belirtilmiştir. Yükseköğrenim mezunu işsizlerin olumsuz bir ruh halinde olduğu, daha çok kaygıya ve strese kapıldıkları tespit edilmiştir (Polat ve Bacak, 2018, s.37).

Üniversite öğrencilerinde işsizlik kaygısı üzerine yapılan bir araştırmada, üniversite son sınıf öğrencilerinin işsizlik kaygısı yaşadıkları belirlenmiştir. İşsizlik kaygısının alt boyutları olarak, çevresel ve sosyal baskı, ekonomideki istihdam daralması, niteliksel olarak bilgi ve beceri eksikliği, kişisel karamsarlık ve özgüven eksikliği olmak üzere dört alt boyut tespit edilmiştir. Üniversite öğrencilerinin büyük çoğunluğu aldıkları eğitimi ve sahip oldukları nitelikleri, işgücü piyasasına girmelerinde ve mesleklerinde iyi bir yere gelmelerinde yetersiz olarak görmektedirler. İşsizlik kaygısı yaşayan öğrencilerin stres, sürekli kaygı, depresyon gibi psikolojik rahatsızlıkları da beraber yaşadıkları tespit edilmiştir (Tekin Tayfun ve Korkmaz, 2016, s.552-556).

İşsizlik olgusunun psikolojik boyutu üzerine yapılan bir araştırmada, erkek işsizlerin depresyon düzeyleri, kadın işsizlere göre daha yüksek bulunmuştur. İş bulma umudu olanlar ile gelecekten umutlu olanların depresyon düzeyi daha düşük bulunmuş, işsizliğin kişinin ruh sağlı̆̆1 üzerinde olumsuz yönde etkisi olduğu belirlenmiştir (Yüksel, 2005, s. 272).

Üniversite öğrencileri üzerinde iş bulamama kaygısı ile ilgili yapılan bir araştırmada, üniversite öğrencilerinin en önemli kaygı nedeni olarak, iş bulamama ve işe girememeyi gösterdikleri tespit edilmiştir. Erkek öğrencilerin iş bulamama ve işe girememe kaygısı, kız öğrencilere göre daha yüksek bulunmuştur (Kaya ve Varol, 2004, s.56).

İşsizliğin psikolojik sonuçları konusunda yapılan araştırmada, işsizlik sürecinde erkeklerin kadınlara göre daha fazla maddi sıkıntı ve daha yüksek düzeyde psikolojik sıkıntı yaşadıkları ve daha depresyonlu oldukları tespit edilmiştir. Bunun nedeninin işsizlik dolayısıyla erkeğin toplumda üstlenmiş olduğu rol ve bu rolün gerektirdiği sorumlulukları yerine getirememesi durumu olabileceği belirtilmiştir (Çizel vd. 2011, s.35). 
İşsizliğin psikolojik etkilerine yönelik bir araştırmada, uzun süren işsizliğin kişilerin kaygı şikayetlerinde artışa yol açtığı, işsizlik süresi arttıkça kaygı düzeyinin de arttı̆̆, işsizliğe verilen kaygı tepkilerinin hızlı bir şekilde ortaya çıktığı tespit edilmiştir (Hammarstrom, ve Janlert, 1997, s.297).

\section{Yöntem}

\section{Araştırmanın Amacı ve Kapsamı}

Araştırmanın temel amacı, üniversite mezunlarının kişilik özellikleriyle işsizlik kaygısı arasında bir ilişki olup olmadığını incelemek ve ayrıca üniversite mezunlarının çeşitli sosyo-demografik değişkenleriyle işsizlik kaygıları arasında, istatistiki açıdan anlamlı bir ilişki olup olmadığını da belirleyebilmektir. Araştırmanın kapsamını üniversiteden mezun olmuş ve iş arama sürecindeki üniversite mezunu işsizler oluşturmaktadır.

\section{Araștırma Modeli}

Araştırmadaki bağımlı değişken işsizlik kaygısı, bağımsız değişken ise beş faktör kişilik özelliklerinden oluşmaktadır. Araştırma nicel bir araştırma olup, bağımsız değişkenlerin bağımlı değişken üzerine etkilerini incelemektedir.

\section{Araştırmanın Evreni ve Örneklemi}

Araştırma evrenini Çankırı Karatekin Üniversitesinden mezun olan ve iş arayan işsizler oluşturmaktadır. Örnekleme yöntemlerinden kolayda örnekleme yöntemi tercih edilmiş ve üniversiteden mezun olan 36.604 kişinin iletişim adreslerine anket formu gönderilmiştir. İş bulamayıp işsiz olduğunu ve iş aradığını beyan eden 1261 üniversite mezunu ankete cevap vererek araştırmaya katılmıştır.

Nicel yönelimli sosyal bilim araştırmaları için \%99 güvenilirlik düzeyinde, kabul edilebilir asgari örneklem büyüklüğü için hazırlanmış tablolara göre, 40.000 kişilik evren için 655 örneklemin yeterli olduğu hesaplanmıştır (Gürbüz ve Şahin, 2017, s.130). Üniversite mezunu 36.604 
kişiden bu araştırmaya 1261 kişi katıldığından, örneklem büyüklüğünün araştırma evrenini yeterince temsil ettiği görülmektedir.

Kişilerden veri toplanan araştırmalar etik kurul iznini gerektirdiğinden, Çankırı Karatekin Üniversitesi Etik Kurulu'ndan 12.05.2020 tarihinde, araştırmanın uygulanabilirliği konusunda bilimsel araştırmalar etiği açısından bir sakınca olmadığına ilişkin etik kurul izni alınmıştır.

\section{Veri Toplama Yöntemi ve Araçları}

İşsiz üniversite mezunlarının kişilik özellikleriyle işsizlik kaygıları arasındaki ilişkileri ölçmek amacıyla gerekli olan veriler, anket yöntemiyle iş arayan üniversite mezunlarından toplanmıştır. Çalışmada kullanılacak verileri elde etmek için hazırlanan anket formu toplam 36 sorudan oluşmaktadır.

Demografik Bilgi Formu: Üniversite mezunu iş arayanların, cinsiyeti, yaş aralığı, medeni durumu, öğrenim durumu, iş arama süresi, kendi işini kurma yani girişimciliği düşünme durumunu içeren altı soru bulunmaktadır.

İşsizlik Kaygısı Ölçeği: Eş ve Durak tarafından 2018 yılında geliştirilen iş bulma kaygısı ölçeğindeki ifadelerden yararlanılarak, yirmi ifadeden oluşan işsizlik kaygısı ölçeği geliştirilmiştir.

Beş Faktör Kişilik Ölçeği: Kişilik özelliklerini beş faktöre göre ölçmek için Gosling vd. tarafından geliştirilen ölçek, kişilik özelliği olarak uyumluluk, dışa dönüklük, sorumluluk, deneyime açıklık ve duygusal denge olmak üzere beş alt faktörden oluşmaktadır (Gosling vd. 2003, s. 525).

Ölçeklerde yer alan ifadeler, en olumsuz kesinlikle katılmıyorum ifadesi bir, en olumlu kesinlikle katılıyorum ifadesi beş olmak üzere, beş aralıklı Beşli Likert tipi ölçekle ölçülmüştür.

\section{Ölçeğin Güvenilirliği}

İşsizlik kaygısı ölçeğinin Cronbach's Alpha güvenilirlik katsayısı 0.732 olarak hesaplanmış ve ölçeğin güvenilirliğinin yüksek olduğu tespit edilmiştir. Beş faktör kişilik ölçeğinin alt boyutlarının Cronbach's Alpha güvenilirlik katsayıları; dışa dönüklük için 0.722, uyumluluk için 0.702, 
sorumluluk için 0.707, duygusal dengelilik için 0.706, deneyime açıklık için 0.734 olarak hesaplanmış ve ölçeğin güvenilirliğinin yüksek olduğu belirlenmiştir. Bu ölçeğin Türk kültüründe kişilik özelliklerini belirlemede kullanılabilecek geçerli ve güvenilir bir ölçme aracı olduğu yapılan bilimsel çalışmalarla da tespit edilmiştir (Atak, 2013, s.317).

\section{Araştırmanın Hipotezleri}

Araştırmaya katılan üniversite mezunu iş arayanların işsizlik kaygılarıyla, cinsiyet, yaş, medeni durum, öğrenim durumu, iş arama süresi, girişimciliği düşünme değişkenlerine göre ve ayrıca kişilik özellikleriyle işsizlik kaygıları arasındaki ilişkilere göre hipotezler kurulmuştur.

H1: Üniversite mezunlarının işsizlik kaygıları cinsiyete göre istatistiki açıdan anlamlı farklılık gösterir.

H2: Üniversite mezunlarının işsizlik kaygıları yaşa göre istatistiki açıdan anlamlı farklılık gösterir.

H3: Üniversite mezunlarının işsizlik kaygıları medeni duruma göre istatistiki açıdan anlamlı farklılık gösterir.

H4: Üniversite mezunlarının işsizlik kaygıları eğitim durumuna göre istatistiki açıdan anlamlı farklılık gösterir.

H5: Üniversite mezunlarının işsizlik kaygıları iş arama süresine göre istatistiki açıdan anlamlı farklılık gösterir.

H6: Üniversite mezunlarının işsizlik kaygıları girişimci olmayı düşünmelerine göre istatistiki açıdan anlamlı farklılık gösterir.

H7: Üniversite mezunlarının kişilik özellikleri ile işsizlik kaygıları arasında anlamlı bir ilişki vardır.

H71: Dışa dönüklük kişilik özelliğinin işsizlik kaygısı üzerinde anlamlı bir etkisi vardır.

H72: Uyumluluk kişilik özelliğinin işsizlik kaygısı üzerinde anlamlı bir etkisi vardır.

H73: Sorumluluk kişilik özelliğinin işsizlik kaygısı üzerinde anlamlı bir etkisi vardır.

H74: Duygusal denge kişilik özelliğinin işsizlik kaygısı üzerinde anlamlı bir etkisi vardır.

H75: Deneyime açıklık kişilik özelliğinin işsizlik kaygısı üzerinde anlamlı bir etkisi vardır. 


\section{Verilerin Analizi}

İşsiz olduğunu beyan eden üniversite mezunlarından anketlerle toplanan veriler SPSS paket programının 22. versiyonuyla analiz edilmiştir. Katılımcıların demografik özellikleri sıklık ve yüzde olarak hesaplanmıştır. Demografik değişkenlerle işsizlik kaygısı arasında istatistiksel açıdan anlamlı bir farklılık olup olmadığı bağımsız gruplar $t$ testi ve ANOVA ile test edilmiştir. Bağımsız değişkenler olan beş faktör kişilik özelliklerinin alt boyutlarıyla, bağımlı değişken olan işsizlik kaygısı arasındaki ilişkiler ve etkileri korelasyon ve regresyon analizleriyle test edilmiştir.

\section{Araştırmanın Kısıtları}

Araştırma bulguları, Çankırı Karatekin Üniversitesinden mezun olan, işsiz olduğunu ve iş aradığını beyan eden üniversite mezunu işsizlerle sınırlıdır. Araştırma belirli bir zaman aralığında yapıldığından dolayı kesitsel bir araştırmadır. Araştırmada elde edilen kişilik özellikleri ve işsizlik kaygısına yönelik bulgular ölçeklerin ölçme kapasiteleriyle kısitlıdır.

\section{Araştırmanın Bulguları}

Bu çalışmada 2020 yılı ekim ayına kadar Çankırı Karatekin Üniversitesinden mezun olan ancak henüz bir iş bulamadığını beyan eden mezunların, işsizlik kaygılarına ilişkin tutumları ve bunların kişilik özellikleriyle ilişkileri araştırılmıştır. Araştırma evrenini Çankırı Karatekin Üniversitesi mezunları oluşturmaktadır. Araştırmanın örneklemi kolayda örnekleme yöntemiyle seçilen 1261 üniversite mezunundan oluşmaktadır.

\section{Demografik Bulgular}

Araştırmaya katılan kişilerin cinsiyeti, medeni durumu, öğrenim durumu, yaş aralığı, kaç yıldır iş aradığı ve kendi işini kurmayı yani girişimci olmayı düşünme durumlarına ilişkin cevaplarının frekansları ve yüzdeleri hesaplanmıştır. 
Tablo 2. Araştırmaya katılan üniversite mezunlarının özelliklerinin sıklık dağılımı

\begin{tabular}{llll}
\hline Değişkenler & Gruplar & S1klık & Yüzde (\%) \\
\hline Cinsiyeti & Kadın & 798 & 63.3 \\
Medeni Durumu & Erkek & 463 & 36.7 \\
& Bekâr & 1001 & 79.4 \\
Eğitim Durumu & Evli & 260 & 20.6 \\
& Ön lisans (MYO) & 265 & 21.0 \\
& Lisans & 848 & 67.2 \\
Yaş Aralığı & Lisansüstü & 148 & 11.8 \\
& 24 yaş ve altı & 499 & 39.6 \\
Girişimci olmayı düşünü- Evet & 734 & 58.2 \\
yor mu? & 25-34 yaş arası & 28 & 2.2 \\
& Hayır & 664 & 52.7 \\
İş arama süresi & & 597 & 47.3 \\
& 1 yıldan az & 557 & \\
& 1-3 yıl arası & 533 & 44.2 \\
& 3-6 yıl arası & 118 & 42.3 \\
& 6 yıldan fazla & 53 & 9.4 \\
\hline
\end{tabular}

Tablo 2'de görüldüğü gibi araştırmaya katılan 1261 kişinin 798'i $(\% 63,3)$ kadın, 463'ü $(\% 36,7)$ erkektir. Bunlardan 1001'i bekâr, 260'1 evli olduğunu beyan etmiştir. Öğrenim durumu itibariyle, 848'i $(\% 67,2)$ lisans mezunu olarak ilk sırada yer almakta, bunu 265 (\%21) ile önlisans iki yıllık meslek yüksekokulu mezunları takip etmekte ve 148'i de $(\% 11,8)$ yüksek lisans mezunlarından oluşmaktadır. Yaş aralığı itibariyle 25-34 yaş aralığındakiler $734(\% 58,2)$ ile ilk sirada yer almakta, bunu $499(\% 39,6)$ ile 24 yaş ve altındakiler takip etmekte ve $28(\% 2,2)$ gibi çok az sayıda 35 yaş ve üstündekiler bulunmaktadır. Kendi işini kurmayı yani girişimci olmayı 664'ü $(\% 52,7)$ düşündüğünü ifade etmiştir. İş arama süreleriyle ilgili 557'si $(\% 44,2)$ bir yıldan az süredir iş aradığını, 533'ü $(\% 42,3)$ bir üç yıl arası iş aradığını belirtmişlerdir.

\section{Hipotez Testleri}

Üniversite mezunu işsizlerin sosyo demografik özellikleri ve kişilik özelikleriyle işsizlik kaygıları arasındaki ilişkileri ölçmek amacıyla oluşturulan hipotezler, çeşitli istatistiki tekniklerle test edilmiştir.

H1: "Üniversite mezunlarının işsizlik kaygıları cinsiyete göre istatistiki açıdan anlamlı farklılık gösterir" hipotezi bağımsız örneklem $t$ testi ile test edilmiştir. 
Tablo 3. Üniversite mezunlarının cinsiyetleriyle işsizlik kaygısı ilişkilerine yönelikt testi sonuçları

\begin{tabular}{lllllll}
\hline Cinsiyeti & Say1 & Ortalama & Standart Sapma & s.d. & T & P \\
\hline Kadın & 798 & 3,9068 &, 37573 & 784 & 1,156 & \multirow{2}{*}{248} \\
Erkek & 463 & 3,8766 &, 48534 & & & \\
\hline
\end{tabular}

Tablo 3'teki bağımsız örneklem $t$ testi sonuçlarına göre $\mathrm{P}=0,248$ ve $\mathrm{P}>0,05$ olduğundan üniversite mezunlarının işsizlik kaygılarının cinsiyete göre istatistiki açıdan anlamlı farklılık göstermediği bulunmuştur. Üniversite mezunu kadınların işsizlik kaygıları ortalamasıyla, üniversite mezunu erkeklerin işsizlik kaygıları ortalamaları çok yakın olduğundan, cinsiyete göre işsizlik kaygıları açısından anlamlı bir fark bulunamamış ve H1 hipotezi reddedilmiştir.

H2: "Üniversite mezunlarının işsizlik kaygıları yaşlarına göre istatistiki açıdan anlamlı farklılık gösterir" hipotezi, araştırmada üç farklı yaş grubu olduğundan ANOVA ile test edilmiştir.

Tablo 4. Üniversite mezunlarının yaşlarıyla işsizlik kaygılan ilişkilerine yönelik ANOVA sonuçları

\begin{tabular}{llllll}
\hline \multicolumn{1}{c}{ Yaş Aralığı } & Sayı & Ortalama & Standart Sapma & F & P \\
\hline 24 yaş ve altı & 499 & 3,9280 &, 40117 & 2,824 &, 060 \\
25-34 yaş aralığı & 734 & 3,8772 &, 42928 & & \\
35 yaş ve üzeri & 28 & 3,8071 &, 44715 & & \\
\hline
\end{tabular}

Üniversite mezunlarının yaş aralıklarına göre işsizlik kaygılarının ANOVA analizi sonuçlarına göre, $\mathrm{P}=0,060$ bulunmuştur. $\mathrm{P}>0,05$ olduğundan, yaş grupları arasında işsizlik kaygıları bakımından istatistiki açıdan anlamlı bir farklılık olmadığı tespit edilmiştir. Mezunların işsizlik kayg1ları yaşlarına göre istatistiki açıdan anlamlı farklılık gösterir şeklindeki H2 hipotezi reddedilmiştir.

H3: “Üniversite mezunlarının işsizlik kaygıları medeni duruma göre istatistiki açıdan anlamlı farklılık gösterir" hipotezi bağımsız örneklem t testi ile test edilmiştir.

Tablo 5. Üniversite mezunlarının medeni durumlarıyla işsizlik kaygısı ilişkilerinin $t$ testi sonuçları

\begin{tabular}{lllllll}
\hline Medeni Durum & Sayı & Ortalama & Standart Sapma & s.d. & t & P \\
\hline Bekar & 1001 & 3,9173 &, 40483 & & & \\
Evli & 260 & 3,8125 &, 46273 & 1259 & 3,608 &, 000 \\
\hline
\end{tabular}


Tablo 5'te mezunların medeni durumlarına göre işsizlik kaygılarının $t$ testi sonuçları görülmektedir. Bu sonuçlara göre $\mathrm{P}=0.000<0.05$ olduğundan, bekar ve evli gruplar arasında işsizlik kaygıları bakımından istatistiki açıdan anlamlı farklılık olduğunu göstermektedir. Bekarların ortalaması evlilerden daha yüksek çıktığından, bekarların daha çok işsizlik kaygısı duyduğu görülmektedir. Üniversite mezunlarının işsizlik kaygıları medeni duruma göre istatistiki açıdan anlamlı farklılık gösterir şeklinde kurulan $\mathrm{H} 3$ hipotezi kabul edilmiştir.

H4: "Üniversite mezunlarının işsizlik kaygıları eğitim durumlarına göre istatistiki açıdan anlamlı farklılık gösterir" hipotezi, üç farklı grup olduğundan ANOVA ile test edilmiştir.

Tablo 6. Üniversite mezunlarının eğitim durumlarıla işsizlik kaygısı ilişkilerinin ANOVA sonuçları

\begin{tabular}{llllll}
\hline Eğitim Durumu & Sayı & Ortalama & Standart Sapma & F & P \\
\hline Önlisans (MYO) & 265 & 3,8685 &, 47464 & 1,142 &, 320 \\
Lisans & 848 & 3,9081 &, 39720 & & \\
Lisansüstü & 148 & 3,8733 &, 43727 & & \\
\hline
\end{tabular}

Tablo 6'da mezunların eğitim durumlarına göre, işsizlik kaygılarının farklılaşıp farklılaşmadığına yönelik kurulan H4 hipotezinin ANOVA sonuçları görülmektedir. Buna göre $\mathrm{P}=0.320>0.05$ olduğundan eğitim durumlarına göre işsizlik kaygıları bakımından istatistiki açıdan anlamlı bir fark görülmediğinden H4 hipotezi reddedilmiştir. Üniversite mezunlarının işsizlik kaygılarının, iki yıllık meslek yüksekokulu yani önlisans, lisans veya yüksek lisans mezunu olmalarına göre istatistiki açıdan anlamlı bir fark oluşturmadığı söylenebilir.

H5: “Üniversite mezunlarının işsizlik kaygıları iş arama süresine göre istatistiki açıdan anlamlı farklılıklar gösterir" hipotezi, dört farklı grup olduğundan ANOVA ile test edilmiştir.

Tablo 7. Üniversite mezunlarının iş arama sürelerine göre işsizlik kaygılarının ANOVA sonuçları

\begin{tabular}{llllll}
\hline İş Arama Süresi & Sayı & Ortalama & Standart Sapma & F & P \\
\hline 1 yıldan az & 557 & 3,8452 &, 46620 & 7,227 &, 000 \\
1-3 yıl arası & 533 & 3,9537 &, 35241 & & \\
3-6 yll arası & 118 & 3,9161 &, 35972 & & \\
6 yıldan fazla & 53 & 3,7991 &, 55127 & & \\
\hline
\end{tabular}


Tablo 7'de iş arama sürelerine göre işsizlik kaygılarının ANOVA sonuçları görülmektedir. Bu sonuçlara göre anlamlılık oranı, $\mathrm{P}=0.000<0.05$ olduğundan iş arama süreleriyle işsizlik kaygıları arasında istatistiki açıdan anlamlı farklılık bulunmuş ve $\mathrm{H} 5$ hipotezi kabul edilmiştir. Bu farkl1lığın hangi gruplar arasında olduğuna yönelik çoklu karşılaştırma Tukey HSD testi yapılmıştır.

Tablo 8. Üniversite mezunlarının iş arama süreleriyle işsizlik kaygılarna yönelik Tukey HSD analizi

\begin{tabular}{lllll}
\hline İş Arama Süresi (I) & İş Arama Süresi (J) & Ort. Farkı (I-J) & Std. Hata & Anlamlılık \\
\hline \multirow{3}{*}{ 1 yıldan az } & 1-3 yıl arası &,$- 10851^{*}$ &, 02523 &, 000 \\
& 3-6 yll arası &,- 07095 &, 04219 &, 334 \\
& 6 yyldan fazla &, 04610 &, 05984 &, 868 \\
& 1 yıldan az &, $10851^{*}$ &, 02523 &, 000 \\
1-3 yıl arası & 3-6 yıl arası &, 03756 &, 04235 &, 812 \\
& 6 yılddan fazla &, $15460^{*}$ &, 05996 &, 049 \\
& 1 yyldan az &, 07095 &, 04219 &, 334 \\
3-6 yll arası & 1-3 yıl arası &,- 03756 &, 04235 &, 812 \\
& 6 yıldan fazla &, 11705 &, 06884 &, 324 \\
& 1 yılddan az &,- 04610 &, 05984 &, 868 \\
6 yıldan fazla & 1-3 yll arası &,$- 15460^{*}$ &, 05996 &, 049 \\
& 3-6 yıl arası &,- 11705 &, 06884 &, 324 \\
\hline
\end{tabular}

Tablo 8'de gruplar arasındaki farklılığın hangi gruptan kaynaklandığına yönelik yapılan Tukey HSD testinin sonuçları görülmektedir. Gruplar arası farklılığın 1-3 yıl arası iş arayan gruptan kaynaklandığı, 1-3 yıl arası grupla 1 yıldan az iş arayan grup ve 6 yıldan fazla iş arayan grup arasında anlamlı bir farklılığın olduğu ve diğer gruplar arasında anlamlı bir farkın olmadığı söylenebilir. 1-3 yıl arası iş arayanların işsizlik kayg1larının diğer gruplardan daha yüksek olduğu görülmektedir.

H6: “Üniversite mezunlarının işsizlik kaygıları, girişimci olmayı düşünmelerine göre istatistiki açıdan anlamlı farklılık gösterir" hipotezi bağımsız örneklem $t$ testi ile test edilmiştir.

Tablo 9. Üniversite mezunlarının girişimci olmayı düşünmeleriyle işsizlik kaygılarrna yönelik t testi sonuçları

\begin{tabular}{lccllll}
\hline $\begin{array}{l}\text { Girişimci Olmayı Düşünme } \\
\text { Durumu }\end{array}$ & Sayı & Ortalama & Standart Sapma & s.d. & t & P \\
\hline Evet & 664 & 3,9029 &, 44094 & 1259 &, 645 &, 519 \\
Hayır & 597 & 3,8877 &, 39424 & & & \\
\hline
\end{tabular}


Tablo 9' da üniversite mezunu iş arayanların girişimci olmayı düşünmeleriyle, işsizlik kaygılarına yönelik bağımsız örneklem t testi sonuçları görülmektedir. Araştırmaya katılan 1261 iş arayan üniversite mezunundan, $664(\% 52,7)$ 'si kendi işini kurmayı düşündüğünü belirtmiştir. Üniversiteden mezun olup henüz bir iş bulamayanların kendi işlerini kurmayı yani girişimci olmayı düşünmeleriyle, işsizlik kaygıları arasındaki ilişki merak edilmiş ve H6 hipotezi kurulmuştur. Yapılan t testi sonuçlarına göre $\mathrm{P}=0.519>0.05$ olduğundan girişimci olmayı düşünenlerle düşünmeyenler arasında işsizlik kaygıları bakımından istatistiki açıdan anlamlı bir fark olmadığ 1 görülmüş ve H6 hipotezi reddedilmiştir.

H7: “Üniversite mezunlarının kişilik özellikleri ile işsizlik kaygıları arasında istatistiki açıdan anlamlı bir ilişki vardır" hipotezi korelasyon ve regresyon ile test edilmiştir.

Tablo 10. Tanımlayıcı İstatistikler

\begin{tabular}{llll}
\hline & Ortalama & Standart Sapma & Sayı \\
\hline İşsizlik kaygısı & 3,8957 &, 41938 & 1261 \\
Dışa dönüklük & 3,9255 &, 99103 & 1261 \\
Uyumluluk & 1,6324 &, 69630 & 1261 \\
Sorumluluk & 4,3351 &, 76048 & 1261 \\
Duygusal denge & 2,3204 & 1,04466 & 1261 \\
Deneyime açılık & 4,4207 &, 81580 & 1261 \\
\hline
\end{tabular}

Tablo 10' da işsizlik kaygısı ve kişilik özelliklerine ilişkin tanımlayıcı istatistikler görülmektedir. Deneyime açıklık kişilik özelliği ilk sırada yer almış, onu sorumluluk ve dışa dönüklük kişilik özelliği takip etmiş ve ortalaması en düşük çıkan kişilik özelliği uyumluluk olmuştur.

Tablo 11. Değişkenler arasındaki ilişkiler

\begin{tabular}{|c|c|c|c|c|c|c|c|}
\hline & & $\begin{array}{l}\text { İşsizlik } \\
\text { Kaygısı1 }\end{array}$ & $\begin{array}{l}\text { Dişa Dö- } \\
\text { nük. }\end{array}$ & Uyumlu. & Sorumlu. & $\begin{array}{l}\text { Duygusal } \\
\text { Denge }\end{array}$ & $\begin{array}{l}\text { Deneyime } \\
\text { Açıklık }\end{array}$ \\
\hline \multirow{6}{*}{$\begin{array}{l}\text { Pearson } \\
\text { yon }\end{array}$} & Korelas- İşsizlik Kaygısı & ,000 & 041 &,- 084 &,- 111 & 049 & 066 \\
\hline & Dışa Dönüklük &,- 041 & 1,000 &,- 196 & ,295 &,- 331 &, 317 \\
\hline & Uyumluluk & -084 & -196 & 1,000 &,- 297 & ,459 &,- 146 \\
\hline & Sorumluluk &,- 111 & ,295 &,- 297 & 1,000 &,- 289 & ,346 \\
\hline & Duygusal Denge & ,049 &,- 331 & 459 &,- 289 & 1,000 &,- 178 \\
\hline & Deneyime Açıklık &,- 066 & 317 &,- 146 & ,346 &,- 178 & 1,000 \\
\hline \multirow{6}{*}{$\begin{array}{l}\text { Sig. } \\
\text { (1-tailed) }\end{array}$} & İşsizlik Kaygısı & . & 072 & ,001 & ,000 & ,041 & 009 \\
\hline & Dışa Dönüklük & 072 & .. & 000 & 000 & 000 & 000 \\
\hline & Uyumluluk & 001 & 000 & . & 000 & 000 & 000 \\
\hline & Sorumluluk & ,000 & 000 & 000 & . & 000 & 000 \\
\hline & Duygusal Denge &, 041 & 000 & 000 & 000 & . & 000 \\
\hline & Deneyime Açılklk & 009 & 000 & 000 & 000 & 000 & . \\
\hline
\end{tabular}


Tablo 11'de bağımlı değişken olan işsizlik kaygısıyla, bağımsız değişkenler olan kişilik özellikleri arasındaki ikili korelasyonlar görülmektedir. Bağımlı değişken olan işsizlik kaygısıyla, bağımsız değişkenler olan dışa dönüklük, uyumluluk, sorumluluk, deneyime açıklık arasında negatif yönlü ve düşük derecede bir ilişki tespit edilmiştir. Sadece duygusal denge kişilik özelliği ile işsizlik kaygısı arasında pozitif yönlü ve düşük seviyede bir ilişki bulunmuştur. Bunlardan uyumluluk, sorumluluk, duygusal denge ve deneyime açıklık ile işsizlik kaygısı arasındaki ilişki (sig.<0,05) olduğundan anlamlı gözükmektedir.

Bağımsız değişkenler olan kişilik özelliklerinin, bağımlı değişken olan işsizlik kaygısı üzerindeki etkisini belirlemek için regresyon analizi yapılmiştır.

Tablo 12. Regresyon modeli özeti

\begin{tabular}{lllll}
\hline Model & $\mathrm{R}$ & $\mathrm{R}^{2}$ & Düzeltilmiş $\mathrm{R}^{2}$ & Std. Tahmin Hatası \\
\hline 1 &, $183^{\mathrm{a}}$ &, 034 &, 030 &, 41309 \\
\hline
\end{tabular}

a. Tahminler (Sabit): Deneyime açıklık, Uyumluluk, Dışa dönüklük, Sorumluluk, Duygusal denge

Tablo 12'de deneyime açıklık, uyumluluk, dışa dönüklük, sorumluluk ve duygusal denge bağımsız değişkenlerinin, işsizlik kaygısı bağımlı değişkeni üzerindeki etkisini gösteren regresyon oranı 0,183 olarak görülmektedir. Bu beş bağımsız değişken, bağımlı değişkendeki değişmelerin \%3,4'ünü açıklamaktadır.

Tablo 13. Çoklu regresyon modelinin anlamlılık sonuçları - (ANOVAa)

\begin{tabular}{lllllll}
\hline Model & & Kareler Toplamı & Sd & Kareler Ortalaması & F & Sig. \\
\hline 1 & Regresyon & 7,456 & 5 & 1,491 & 8,739 &, $000^{\mathrm{b}}$ \\
& Atık (Residual) & 214,156 & 1255 &, 171 & & \\
& Toplam & 221,612 & 1260 & & & \\
\hline
\end{tabular}

a. Bă̆ımlı Değişken: İssizlik Kaygısı

b. Tahminler (Sabit): Deneyime açıklık, uyumluluk, dışadönüklük, sorumluluk, duygusal denge

Tablo 13'e göre F testinin anlamlılık değeri 0,05 den küçük (Sig.=0.000) olduğundan regresyon modeli önemli olup tahminde kullanılabilir. Deneyime açılık, uyumluluk, sorumluluk, duygusal denge ve dışa açıklık değişkenlerinin işsizlik kaygısı üzerindeki etkisi istatistiki açıdan anlamlıdır. 
Dolayısıyla üniversite mezunlarının kişilik özellikleri ile işsizlik kaygıları arasında anlamlı bir ilişki vardır şeklindeki H7 hipotezi kabul edilmiştir.

Tablo 14. Çoklu regresyon modeline ilișkin katsayılara

\begin{tabular}{|c|c|c|c|c|c|c|}
\hline & \multirow[t]{3}{*}{ Model } & \multicolumn{5}{|c|}{ Standartlaştırılmamış Katsa- Standart Katsayılar } \\
\hline & & \multicolumn{3}{|c|}{ yilar } & \multirow[t]{2}{*}{$\mathrm{t}$} & \multirow[t]{2}{*}{ Sig. } \\
\hline & & B & Std. Hata & Beta & & \\
\hline \multirow[t]{6}{*}{1} & (Sabit) & 4,350 & ,106 & & 41,226 & ,000 \\
\hline & Dışa Dönüklük & ,001 & ,013 & ,001 & ,042 & ,967 \\
\hline & Uyumluluk &,- 098 & ,019 & 163 & $-5,115$ & ,000 \\
\hline & Sorumluluk &,- 069 & 017 & -125 & $-3,995$ & ,000 \\
\hline & Duygusal Denge & ,033 & ,013 & ,082 & 2,507 & 012 \\
\hline & Deneyime Açılık & -017 & ,016 & -032 & $-1,065$ & ,287 \\
\hline
\end{tabular}

a. Bağımlı Değişken: İsssizlik kaygısı

Tablo 14'te regresyon analizi sonucunda bağımsız değişken olan kişilik özelliklerinin bağımlı değişken olan işsizlik kaygısı üzerindeki etkileri görülmektedir. Standart Beta katsayısına göre, bağımsız değişkenlerin bağımlı değişken üzerindeki önem sırası uyumluluk (Beta=-,163), sorumluluk (Beta=-,125), duygusal denge (Beta=,082), deneyime açılık (Beta=,032) ve dışa dönüklük (Beta=,001) şeklinde sıralanmaktadır.

Regresyon katsayılarının anlamlılığına ilişkin $\mathrm{t}$ testi sonuçlarına göre; dışa dönüklük değişkeninin işsizlik kaygısı üzerinde anlamlı bir etkisi yoktur (Sig.=,967>0,05). Buna göre “Dışa dönüklük kişilik özelliğinin işsizlik kaygısı üzerinde anlamlı bir etkisi vardır" şeklindeki H7ı hipotezi reddedilmiştir.

Uyumluluk değişkeninin işsizlik kaygısı üzerindeki etkisine yönelik $\mathrm{t}$ testinin sonuçlarına göre, anlamlılık değeri (Sig.=,000<0,05) bulunmuştur. Bu sonuçlara göre, "Uyumluluk kişilik özelliğinin işsizlik kaygısı üzerinde anlamlı bir etkisi vardır" şeklindeki $\mathrm{H} 72$ hipotezi kabul edilmiştir.

Sorumluluk kişilik özelliğinin işsizlik kaygısına etkisine yönelik $\mathrm{t}$ testi sonuçlarına göre anlamlılık değeri (Sig.=,000<0,05) bulunmuştur. "Sorumluluk kişilik özelliğinin işsizlik kaygısı üzerinde anlamlı bir etkisi vardır" şeklinde kurulan $\mathrm{H}_{3} 3$ hipotezi kabul edilmiştir.

“Duygusal denge kişilik özelliğinin işsizlik kaygısı üzerinde anlamlı bir etkisi vardır" şeklinde ifade edilen $\mathrm{H}_{4}$ hipotezi test edilmiştir. Yapılan regresyon katsayılarının anlamlılığına ilişkin $t$ testi sonuçlarına göre, anlamlılık değeri (Sig. $=, 000<0,05)$ olduğundan, $\mathrm{H}_{4}$ hipotezi kabul edilmiştir. 
“Deneyime açılık kişilik özelliğinin işsizlik kaygısı üzerinde anlamlı bir etkisi vardır" şeklinde kurulan $\mathrm{H}_{5}$ hipotezi regresyon katsayılarının anlamlılığına ilişkin $\mathrm{t}$ testi ile test edilmiştir. Bu test sonuçlarına göre deneyime açıklık bağımsız değişkeninin anlamlılık değeri (Sig. $=, 287>0,05)$ olduğundan Beta 5 parametresi önemli değildir ve $\mathrm{H} 75$ hipotezi reddedilmiştir. Deneyime açıklık kişilik özelliğinin işsizlik kaygısı üzerinde anlamlı bir etkisi görülmemiştir.

Yapılan regresyon analizi sonucunda kişilik özelliklerinden dışa dönüklük ve deneyime açıklık bağımsız değişkenlerinin, işsizlik kaygısı bağımlı değişkeni üzerinde istatistiki olarak anlamlı bir etkisinin olmadığ bulunmuştur. Kişilik özelliklerinden uyumluluk, sorumluluk ve duygusal denge bağımsız değişkenlerinin ise, işsizlik kaygısı üzerinde istatistiki açıdan anlamlı bir etkisinin olduğu tespit edilmiştir.

\section{Tartışma ve Sonuç}

İnsanların çalışmak istediği halde piyasada geçerli olan ücretten iş bulamaması yani işsizlik konusu ülkeler için önemli sorunların başında gelmektedir. Bu sorun, uzunca bir süre eğitim alarak üniversiteden mezun olan ve iş aradığı halde iş bulamayan gençleri daha çok etkileyebilmekte ve işsizlik kaygısı duymalarına neden olabilmektedir. İnsanların çeşitli kişilik özellikleri de işsizlik kaygılarını etkileyebilmektedir.

Bu araştırma, Çankırı Karatekin Üniversitesi mezunu 36.604 kişi ile yapılmış olup, iş aradığını ve işsiz olduğunu belirten 1261 kişi araştırmaya katılmıştır. İş arayan üniversite mezunlarının 36 sorudan oluşan anket formunu cevaplandırmalarıyla araştırma verileri toplanmış, kurulan hipotezler test edilerek analiz edilmiştir. İşsizlik kaygısı ölçeğinin alt boyutları; istihdam azlığı, deneyimsizlik, çaresizlik ve kişisel yetersizlik olarak belirlenmiştir. Beş faktör kişilik özellikleri ölçeği ise, dışa dönüklük, uyumluluk, sorumluluk, duygusal denge ve deneyime açıklık alt faktörlerinden oluşmuştur.

Üniversite mezunu iş arayan katılımcıların işsizlik kaygılarının, cinsiyetlerine göre değişmediği tespit edilmiştir. İşsiz olup iş arayan üniversite mezunlarının kadın veya erkek olması işsizlik kaygılarını farklılaştırmamaktadır. Kadın ve erkeklerin duydukları işsizlik kaygısı düzeyleri birbirlerine çok yakın bulunmuştur. 
Meslek Yüksekokulu mezunlarıyla yapılan benzer bir araştırmada da işsizlik kaygısı açısından cinsiyete göre anlamlı bir farklılık bulunamamıştır (Tektaş, 2014, s.252). Bu sonuç, bu araştırma bulgularıyla benzerlik göstermektedir. Ancak üniversite öğrencileri üzerinde yapılan başka bir araştırmada erkek öğrencilerin işsizlik kaygı düzeylerinin kadınlara göre yüksek çıkması, bu araştırma sonuçlarından farklılık göstermektedir (Kaya ve Varol, 2004, s.56).

Üniversite mezunu iş arayanların işsizlik kaygılarının yaşlarına göre değişmediği tespit edilmiştir. Değişik yaşlara göre belirlenen yaş grupları arasında işsizlik kaygıları açısından anlamlı bir farklılık bulunamamış, işsizlik kaygısının yaşa göre değişmediği görülmüştür. İş arayan üniversite mezunlarının işsizlik kaygılarının medeni duruma göre farklılaştığı belirlenmiştir. İş arayan bekarların işsizlik kaygılarının evli olanlardan daha yüksek çıkması, bekarların daha çok işsizlik kaygısı duyduklarını göstermiştir.

Üniversite mezunlarının eğitim düzeylerine göre, iki yıllık meslek yüksekokulu yani önlisans, lisans veya yüksek lisans mezunu olmalarına göre, işsizlik kaygılarının anlamlı bir fark oluşturmadığı bulunmuştur. Üniversite mezunlarının iş aradıkları süreye göre de işsizlik kaygıları karşılaştırılmış, 1-3 yıl arası iş arayanların işsizlik kaygılarının diğer gruplardan daha yüksek olduğu görülmüştür.

Araştırmaya katılan 1261 iş arayan üniversite mezunundan, 664'ü (\%52.7) kendi işini kurmayı yani girişimci olmayı düşündüğünü beyan etmiştir. Yapılan istatistiki analiz sonucunda girişimci olmayı düşünenlerle, düşünmeyenler arasında işsizlik kaygıları açısından anlamlı bir fark olmadığı tespit edilmiştir. Üniversite mezunu olup iş arayıp iş bulamayanların yarısından çoğunun kendi işini kurmayı yani girişimci olmayı düşünmeleri ve bunu gerçekleştirmek için çaba sarfetmelerinin işsizliğin azaltılmasında etkisinin olabileceği düşünülmektedir.

Bağımlı değişken olan işsizlik kaygısıyla, bağımsız değişkenler olan dışa dönüklük, uyumluluk, sorumluluk ve deneyime açıklık kişilik özellikleri arasında ikili korelasyonların hesaplanması sonucunda negatif yönlü ve düşük derecede bir ilişki olduğu bulunmuştur. Sadece duygusal denge kişilik özelliği ile işsizlik kaygısı arasında pozitif yönlü ve düşük seviyede bir ilişki bulunmuştur. 
Bağımsız değişken olan kişilik özelliklerinden dışa dönüklük ve deneyime açıklık değişkenlerinin, işsizlik kaygısı bağımlı değişkeni üzerinde istatistiki olarak anlamlı bir etkisinin olmadığ 1 bulunmuştur. Dışa dönük ve deneyime açı kişilik özellikleri gösterenlerin diğerlerine göre daha az işsizlik kaygısı duyduğu görülmektedir. Kişilik özelliklerinden uyumluluk, sorumluluk ve duygusal denge bağımsız değişkenlerinin ise, işsizlik kaygısı üzerinde istatistiki açıdan anlamlı bir etkisinin olduğu tespit edilmiştir. Uyumluluk, sorumluluk ve duygusal denge kişilik özelliklerine sahip olanların işsizlik kaygılarının daha fazla olduğu söylenebilir.

$\mathrm{Bu}$ araştırmaya katılan iş arayan üniversite mezunlarının kendi işini kurma yani girişimcilik eğilimlerinin yüksek olduğu tespit edilmiştir. Üniversite mezunlarının girişimcilik yeteneklerini geliştirerek kendi işlerini kurmalarının teşvik edilmesi, bunun için devlet tarafından danışmanlık, eğitim, kredi gibi çeşitli teşvik araçlarıyla desteklerin sağlanması işsizlik sorununun çözümünde ve mezunların işsizlik kaygılarının azaltılmasinda önemli katkı sağlayabilir.

İşsizlik ve iş bulma kaygısı ile ilgili araştırmaların, veri toplama güçlüğü nedeniyle üniversite mezunları yerine genellikle üniversitede eğitim öğretime devam eden, henüz mezun olmamış ve iş aramayan, mezun olduğunda iş bulup bulamayacağı henüz belli olmayan öğrencilerle yapıldığ1 görülmektedir. Bu araştırmanın üniversiteden mezun olmuş iş arayan ve henüz bir iş bulamamış üniversite mezunlarılya yapılmış olması itibariyle, bu alana daha çok katkı sağlayacağı düşünülmektedir. 


\title{
EXTENDED ABSTRACT
}

\section{The Effect of Personality Traits on Unemployment Anxiety: A Research on University Graduates}

\author{
Hasan Dağlar \\ Çankırı Karatekin University
}

The main purpose of the study is to examine whether there is a relationship between the personality traits of university graduates and unemployment anxiety, and also to determine whether there is a statistically significant relationship between various socio-demographic variables and unemployment concerns of university graduates. The scope of the research consists of university graduates and especially unemployed university graduates in the job search process.

Unemployment anxiety can be explained as the state of sadness, anxiety and tension that arises as a result of not being able to find a job although the person is willing to work and is willing to take the market wages. High unemployment among university graduates and young people and the rapid increase in the number of university graduates increase the level of unemployment anxiety even more.

In a study examining the relationships between personality traits and unemployment, it was determined that extroverted and adaptable people had less unemployment duration, and there was a decrease in neurotic personality traits after finding a job and getting rid of unemployment. It is seen that most of the studies on unemployment anxiety are not conducted with university graduates due to the difficulty of collecting data, but on students who are studying at the university and who are not yet sure whether they will find a job after graduation. It is thought that this research will contribute to the field, as it is conducted on unemployed university graduates who have graduated from university and are looking for a job who have faced unemployment.

The model of the research consists of unemployment anxiety as the dependent variable and the five factor personality traits as the independent variable. The research is a quantitative study and examines the effects of independent variables on the dependent variable. The population of the 
research consists of unemployed job seekers graduated from Çankırı Karatekin University. Among the sampling methods, convenience sampling method was preferred and a questionnaire was sent to the contact addresses of 36,604 university graduates. 1261 university graduates, who declared that they were unemployed and looking for a job and participated in the research by responding to the questionnaire.

The data required to measure the relationship between the personality traits of unemployed university graduates and their unemployment concerns were collected from university graduates who were looking for a job using a survey method. The questionnaire form prepared to obtain the data to be used in the study consists of a total of 36 questions. Whether there is a statistically significant difference between demographic variables and unemployment anxiety was tested with independent groups ttest and ANOVA. The relationships and effects between the five-factor personality traits, which are independent variables, and unemployment anxiety, which is the dependent variable, were tested with correlation and regression analyzes.

Limitations of the study, research findings are limited to unemployed university graduates who graduated from Çankırı Karatekin University and declared that they are unemployed and looking for a job. The research is a cross-sectional study because it was conducted in a certain time period. The findings on personality traits and unemployment anxiety obtained in the study are limited by the measuring capacities of the scales. Hypotheses were established according to the unemployment concerns of university graduate job seekers participating in the research, according to the variables of gender, age, marital status, education status, duration of job search, thinking about entrepreneurship and also according to the relationships between personality traits and unemployment concerns.

Unemployment is one of the most important problems for countries, although people want to work but cannot find a job at the wages prevailing in the market. This problem may affect young people who have graduated from university after a long period of education and cannot find a job even though they are looking for a job, and may cause them to worry about unemployment. Various personality traits of people can also affect unemployment concerns. Sub-dimensions of unemployment anxiety 
scale; underemployment, inexperience, helplessness and personal inadequacy. The five-factor personality traits scale consists of the sub-factors of extraversion, agreeableness, conscientiousness, emotional stability, and openness to experience.

It was determined that the unemployment concerns of the university graduate job seekers did not change according to their gender. The fact that unemployed university graduates looking for a job are male or female does not differentiate unemployment concerns. Unemployment anxiety levels of women and men were found to be very close to each other.

It has been determined that unemployment concerns of university graduate job seekers do not change according to their age. There was no significant difference between age groups determined according to different ages in terms of unemployment concerns, it was observed that unemployment anxiety did not change according to age. It has been determined that unemployment concerns of university graduates looking for a job differ according to marital status. The fact that the unemployment concerns of single job seekers were higher than the married ones showed that single people were more worried about unemployment.

It was found that unemployment concerns did not make a significant difference according to the education level of university graduates and whether they were graduated from two-year vocational school, that is, associate, bachelor's or master's degree. Unemployment concerns of university graduates were also compared according to the length of time they were looking for a job, and it was seen that unemployment concerns of those who were looking for a job between 1-3 years were higher than the other groups.

Of the 1261 job-seeking university graduates who participated in the research, $664(52.7 \%)$ declared that they were considering starting their own business, that is, becoming an entrepreneur. As a result of the statistical analysis, it has been determined that there is no significant difference in terms of unemployment concerns between those who think about being an entrepreneur and those who do not. It is thought that the fact that more than half of those who are university graduates and cannot find a job think of starting their own business, that is, becoming an entrepreneur, and making efforts to achieve this, may have an impact on reducing unemployment. 
As a result of the calculation of bilateral correlations between the dependent variable unemployment anxiety and the independent variables extraversion, agreeableness, responsibility and openness to experience, it was found that there was a negative and low degree relationship. A positive and low level correlation was found only between emotional stability personality trait and unemployment anxiety.

As a result, it was found that the variables of extraversion and openness to experience, which are personality traits, which are independent variables, did not have a statistically significant effect on the dependent variable of unemployment anxiety. It is seen that those who show extrovert and open to experience personality traits have less unemployment anxiety than others. It has been determined that the independent variables of compatibility, responsibility and emotional balance from personality traits have a statistically significant effect on unemployment anxiety. It can be said that those with personality traits of adaptability, responsibility and emotional balance have higher unemployment anxiety.

\section{Kaynakça / References}

Atak, H. (2013). On-Maddeli kişilik ölçeğinin Türk Kültürü'ne uyarlanması. Nöropsikiyatri Arşivi Dergisi, 50, 312-319.

Costa, P. T., McCrae, R. R. ve Dye, D. A. (1991). Facet scales for agreeableness and conscientiousness: A revision of the neo personality inventory, Personality and Individual Differences, 12(9), 887-898.

Cüceloğlu, D. (2017). İnsan ve davranışı. 35. Basım, İstanbul: Remzi Kitabevi.

Çizel, R. B., Güzeller, C. O. ve Mütevellioğlu, N. (2011). İşsizliğin psikolojik sonuçları: Antalya örneği, Çalışma İlişkileri Dergisi, 2(1), 26-41.

Dursun, S. ve Aytaç, S. (2009). Üniversite öğrencileri arasında işsizlik kaygısı. Uludă̆ Üniversitesi İktisadi ve İdari Bilimler Fakültesi Dergisi, 28(1), 7184.

Eş, A. ve Durak, H. S. (2018). Meslek yüksekokulu öğrencilerinin iş bulma kaygılarına yönelik ölçek geliştirme: Abant İzzet Baysal Üniversitesi örneği. Ekonomik ve Sosyal Araştırmalar Dergisi, 14(1), 115-127.

Gosling, S. D., Rentfrow, P. J. ve Swann W. B. (2003). A very brief measure of the big-five personality domains, Journal of Research in Personality, 37, 504-528. 
Güler Kümbül, B. (2006). İşsizlik ve yarattı̆̆ı psiko-sosyal sorunların öğrenilmiş çaresizlik bağlamında incelenmesi. İstanbul Üniversitesi İktisat Fakültesi Mecmuası (Prof.Dr. Toker Dereli'ye Armağan Özel Sayısı), 55(1), 373-394.

Güney, S. (2017). Sosyal psikoloji. 4. Basım, Ankara: Nobel Yayıncllık.

Gürbüz, S. ve Şahin, F. (2017). Sosyal bilimlerde araştırma yöntemleri. 4. Baskı, Ankara: Seçkin Yayıncılık.

Hammarstrom, A. ve Janlert, U. (1997). Nervous and depressive symptoms in a longitudinal study of youth unemployment- selection or exposure?. Journal of Adolescence, 20(3), 293-305. doi: 10.1006/jado.1997.0086.

Karcıoğlu, F. ve Balkaya, E. (2018). Üniversite son sınıf öğrencilerinde işsizlik kaygısı ve girişimcilik niyeti ilişkisi: TRA1 bölgesi örneği. İş Güç Endüstri İlişkileri ve İnsan Kaynakları Dergisi, 20(3), 95-120. doi: 10.4026/isguc.473601.

Kaya, M. ve Varol, K. (2004). İlahiyat fakültesi öğrencilerinin durumluk-sürekli kaygı düzeyleri ve kaygı nedenleri: Samsun örneği. Ondokuz Mayıs Üniversitesi İlahiyat Fakültesi Dergisi, 17(17), 31-63.

Kıcır, B. (2017). Eğitimli genç işsizliği üzerinden işsizlik kaygısına bir bakış. Çalışma ve Toplum Dergisi, 3(54), 1369- 1396.

Kurt, Ş. (2006). İşsizliğin psiko-sosyal sonuçları ve Türkiye üzerine muhtemel etkileri, Sosyal Siyaset Konferanslar Dergisi, 54, 357-379.

Polat E. K. ve Bacak, B. (2018). İşsizliğin psikolojik sonuçları ve işsizlik süresi ilişkisi: Çanakkale'de yükseköğrenim mezunu işsizler üzerinde bir araştırma, Çalışma İlişkileri Dergisi, 9(2), 24-47.

Rammstedt, B. ve Oliver P. J. (2007). Measuring personality in one minute or less: A 10-item short version of the big five inventory in english and german. Journal of Research in Personality, 41, 203-212.

Şentürk, İ. (2019). Türkiye'de işsizlerin iş arama yoğunluğu. Eskişehir Osmangazi Üniversitesi İ̈BF Dergisi, 14(3), 615-630.

Talas, C. (1997). Toplumsal Ekonomi, Ankara: İmge Kitabevi.

Taşğın, Ö., Bozgeyikli, H. ve Boğazlıyan, E. E. (2017). Üniversiteli gençlerin işsizlik kaygıları ile psikolojik dayanıklılıkları arasındaki ilişki. Emek ve Toplum Dergisi, 6(16), 551-567.

Tekin Tayfun, A. N. ve Korkmaz, A. (2016). Üniversite öğrencilerinde işsizlik kaygısı: Süleyman Demirel Üniversitesi öğrencileri üzerinde bir araştırma. Mehmet Akif Ersoy Üniversitesi Sosyal Bilimler Enstitüsü Dergisi, 8(17), 534-558. 
Tektaş, N. (2014). Üniversite mezunlarının kaygı düzeylerinin incelenmesi, Selçuk Üniversitesi Sosyal Bilimler Enstitüsü Dergisi, Dr. Mehmet Yıldız Özel Sayısı, 243-253.

Tutar, H. (2016). Sosyal psikoloji. 3. Baskl, Ankara: Seçkin Yayıncllık.

Türk Dil Kurumu. (2021). Türkçe Sözlük. (Erişim tarihi: 22.01.2021, $h t t p: / / w w w . t d k . g o v . t r /)$.

Türkiye İstatistik Kurumu. (2021). İşgücü istatistikleri. TÜIKK Haber Bülteni, Sayl: 37485. (Erişim tarihi: 11.01.2021. http://www.tuik.gov.tr)

Viinikainen, J. ve Kokko, K. (2012). Personality traits and unemployment: Evidence from longitudinal data. Journal of Economic Psychology, 33(6), 1204-1222.

Yüksel, İ. (2005). İşsizlik olgusunun psikolojik boyutu: Görgül bir araştırma. Ankara Üniversitesi Siyasal Bilgiler Fakültesi Dergisi, 60(3), 255-274.

Yükseköğretim Kurulu. (2021). Yükseköğretim Bilgi Yönetim Sistemi, (Erişim Tarihi: 05.02.2021. https://istatistik.yok.gov.tr/).

\section{Kaynakça Bilgisi / Citation Information}

Dağlar, H. (2021). Kişilik özelliklerinin işsizlik kaygısı üzerine etkisi: üniversite mezunları üzerine bir araştırma. OPUS-Uluslararası Toplum Araştırmaları Dergisi, 18(44), 7638-7667. DOI: 10.26466/opus. 926760. 